\title{
Evaluation of Reliability of Mobile ICT Services
}

\author{
Marian Kowalewski, Ryszard Kobus, and Tomasz Sędek \\ National Institute of Telecommunications, Warsaw, Poland
}

https://doi.org/10.26636/jtit.2021.141420

\begin{abstract}
This article discusses common problems with reliability and availability of ICT services, mainly in mobile networks. Internet access-related services have been examined and traditional service quality assessment methods have been compared with the proposed solutions, with the primary focus placed on availability and reliability of mobile services. The required parameter values describing reliability and quality levels have been defined and proposed.
\end{abstract}

Keywords-reliability, ICT mobile services, user satisfaction.

\section{Introduction}

The problem of ensuring the highest quality of telecommunication services enjoyed by users has been on the agenda for quite some time now. It was finally tackled, in connection with telephony services, in 1994, in the ITU-T E.800 recommendation that contained definitions of terms related to the quality of service. E.800 emphasizes the fact that the opinion of service users forms an important aspect of the overall assessment of any given service. This assumption serves as a basis for determining the degree of user satisfaction. Recommendation E.800 provides:

- primary concepts,

- basic information related to the quality of services and to network performance,

- a set of key performance indicators (KPIs).

Broadband Internet access relying on fixed connections was not offered until the 1990s. The first patent for an asymmetric digital subscriber line (ADSL) was filled in 1988. Initially, twisted-pair telephone cables with digital subscriber line (DSL) systems were used. Then, ADSL was introduced, and cable television networks entered the mainstream by relying on the data-over-cable service interface specification (DOCSIS) technology, offering speeds similar to those achieved with ADSL. The definition of QoS was then extended to cover broadband Internet access as well [1]. It should be noted that in cable networks the number of users and the maximum data transfer rate were known a priori. Therefore, ensuring the quality of service was relatively simple. However, due to concerns regarding competitive pricing, the services were offered as a "best effort delivery", i.e. without promising the same speeds at all times.

Usually, a given service is offered with a transfer rate that exceeds the users' typical needs, and some loss of speed is acceptable.

In wireless radio networks, QoS parameters depend also, to a considerable degree, on the following [2]:

- user location,

- season (of the year),

- day of the week,

- time of day.

The related model of Internet access is presented in Fig. 1 [3], [4]. It presents the chain of a typical use of Internet service from the user's terminal through the access network (wire or wireless) and the backbone network to the content provider's server (Internet service). The research and practice show that each of the presented components of the model introduces some throttling limitations in the transmission of data packets.

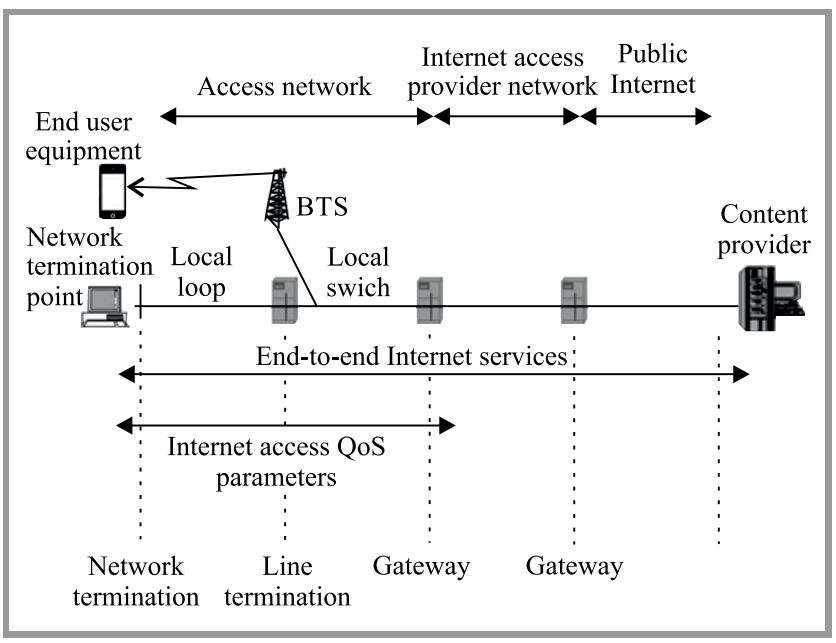

Fig. 1. Internet service provision model.

\section{Research on the Quality of Services}

We should take into account that Internet access-related needs of PC computer and smartphone users vary signifi- 
cantly. Smartphone owners are highly mobile, but accept slightly lower data transmission speeds. Smartphone users are currently the largest and continuously growing group of mobile network users. For many of them, the smartphone has become a basic communication tool used during business and tourist travel. Such users need to use navigation data, tourist guides, apps containing timetables and routes, as well as those allowing to purchase city and regional transportation tickets. Social applications, video calls, etc. are used as well.

Unlike in the case of cable-based services, mobile service providers (operators) cannot control the number of users in a given area. Usually, the operator manages several networks relying on different telecommunication generations and technologies. Such an approach provides room for optimization, each user may be connected to a network that provides transmission speed that is optimized for a given location at current network load. The maximum transfer rate is defined for each frequency band, bandwidth or combination of both band and bandwidth, network configuration and type of equipment used, and is shared with a group of users.

The quality of service provided could be examined inter alia based on the parameters specified in QoS [5] or based on other measurements, such as quality of services dedicated to tourists [6].

In the European Union (EU), a document [7] issued by the Body of European Regulators for Electronic Communications (BEREC) serves as a guide related to the quality of services. It was drawn up in the process of implementing the European Electronic Communications Code (EECC) Directive [8]. The quality of service is defined, in the said document, in the form of the ITU-T Recommendation Y.2617 [9]. The document includes complex QoS parameters concerning Internet access services, including delay, jitter, and packet loss ratio.

Data throughput is a parameter that depends on conditions being beyond the control of the operator, and, therefore, cannot be guaranteed, but exerts a significant impact on QoS.

QoS measurements may be performed using dedicated testers installed at selected locations, or with the use of mobile equipment in vehicles traveling along selected routes [10]. Most often, these will include the most important public roads. Radio signal coverage is assessed based on computer simulations augmented with measurements performed at selected locations. Measurements covering the entire area on which a given service is rendered are too expensive.

\section{Definition of Reliability of ICT Services}

As far as the operation of equipment, devices and networks is concerned, and in terms of ICT services, the reliability of these components becomes increasingly important. Most often it is perceived in two ways, from the point of view of the user and service provider, in this case referred to as the operator.

Reliability is a property of the system and of the ICT network that is related to the ability to perform tasks efficiently, i.e. to the availability of a defined range of services that are rendered in accordance with the intended use and under specific operating conditions. One may assume that reliability is the ability of the system and of the network to provide ICT services. Reliability is also defined by the ability of operator's organization to provide a specific service characterized by parameters expected by customers, under specific operating conditions affecting the telecommunications network.

From the user's point of view, QoS and reliability are defined in terms of their perception, i.e. satisfaction with ICT services provided to match their needs. From this point of view, assessment indicators play an important role in the process of evaluating the service, being a measure describing the degree to which the requirements have been fulfilled.

The research ${ }^{1}$ carried out shows that availability of IT services is related to reliability of ICT services. Accessibility is a specific requirement and also a specific indicator describing the degree to which service reliability-related expectations have been fulfilled. Availability of a service means the ability to rely on that service, to a specific degree and in accordance with the user's needs, with the said degree (scope) of the service indicated in the contract for its provision and agreed upon between the operator and the service recipient (user or customer). In other words, availability means the ability to obtain services at the user's request, in accordance with a defined scope and under specific conditions.

Availability of a service is closely related to the timeliness of communication, understood as the ability of devices and IT networks to ensure the transmission of information within a predefined period of time [11]. This underscores the role and the importance of the service provider in ensuring timeliness, as well as availability and reliability of communication.

Review of the literature indicates that, initially, reliability was used mainly for describing specific features of technical devices and systems [12]. Currently, the concepts of reliability and durability are also applied in system modeling and in software quality models [5], [6], [13]. In addition, it should be noted that an attempt was made in [14] to apply these terms for the assessment of non-technical parameters related to the services provided.

\section{Testing Reliability and Quality}

As far as reliability of ICT services is concerned, work is underway to assess the impact of reliability and qual-

${ }^{1}$ Research performed as part of scientific (statutory) activities of the National Institute of Telecommunications and the Warsaw University of Technology (Poland) in 2016-2018. 
ity of service on customer satisfaction [13]. This approach adheres to the principle of testing services in accordance with the end-to-end concept. The problem of researching end-to-end services in mobile networks has been comprehensively addressed by RootMetrics [15]. For the purpose of this paper, a methodology used for assessing achievement of the expectations of an end user relying on a device that is typical of a specific Internet service is determined. It takes into account the time of day and the location of the user to evaluate service availability and its perceivable quality. In [15], it is estimated that the assessment methodology in question is better correlated with the feelings of users of ICT services than research conducted based on the approach used in the case of traditional fixed networks.

Initially, a set of QoS indicators describing the quality of ICT services for fixed networks was developed. These indicators assess mainly the degree of fulfillment of the business contract or of the operator's promises, with the results presented as a score that is based on a series of tests or measurements during which the maximum capacity of the network in question was sought [16], [17]. These measurements were used mainly to assess performance of the network in terms of access thereto.

In the case of wireless radio networks, the studies conducted show that third, fourth and fifth generation mobile technologies are not capable of offering stable parameters pertaining to ICT services due to their dependence on:

- base station technology and cell capacity,

- type of user device and its technical advancements,

- network load, e.g. the number of active users using one base station,

- location, i.e. the user's distance to the nearest base station,

- date and time of day.

\section{Proposed Solution}

Mobile users are not usually interested in the maximum transmission speed offered by the network, but in achieving data throughput that is sufficient for their needs, their location and the services they use, with a satisfactory level of quality and reliability guaranteed as well. The research shows that the maximum transmission speed is achieved only during speed tests. Under real conditions, performance is often inferior. Service providers should therefore consider parameters guaranteeing that services may be provided to end users with satisfactory reliability and quality levels. The necessary network resources need to be estimated, as it has already been done, in practice, in [4], but only for a scenario in which the end user utilizes a personal computer. Currently, the recommended set of QoS indicators [7], [9] no longer includes transmission speed. Hence, the interest of the regulatory agencies in this indicator has decreased significantly.

At this point, the question arises whether the user's needs will be the same everywhere and at any time. Research shows that the same type of service will generate different experience on a high-performance computer and on a tablet or smartphone (with a smaller screen and less advanced processors). This is due to two reasons: the user's terminal (smartphone) may generate larger restrictions concerning the service rendered than a device operating within a fixed network. The service provider may adapt the content to the type of the user's terminal. To improve accessibility to information, websites are usually available in their mobile version as well, or are accessible through a dedicated application (proxy). It is often the case that they are adapted to smaller screens, which results in the fact that presentation of the mobile version of a web page requires lower data transfers.

The minimum values of network access-related parameters that need to be met to render selected ICT services using a PC computer and a smartphone are presented in Tables 1 and 2 , respectively.

Table 1

Minimum requirements concerning network access parameters that need to be fulfilled to provide services using a PC computer, based on [4]

\begin{tabular}{|c|c|c|}
\hline Application group & Transmission speed (download/upload) above & Delay of up to \\
\hline \hline Browsing websites & $1 \mathrm{Mb} / \mathrm{s} \mathrm{DL}$ & $200 \mathrm{~ms}$ \\
\hline Watching videos in SD quality & $2 \mathrm{Mb} / \mathrm{s} \mathrm{DL}$ & $200 \mathrm{~ms}$ \\
\hline Viewing videos in HD quality & $6 \mathrm{Mb} / \mathrm{s} \mathrm{DL}$ & $150 \mathrm{~ms}$ \\
\hline HD video calls & $1.5 \mathrm{Mb} / \mathrm{s} \mathrm{DL} / \mathrm{mL}$ & $150 \mathrm{~ms}$ \\
\hline Telephone services using VoIP technology & $64 \mathrm{~Kb} / \mathrm{s} \mathrm{DL} / \mathrm{LL}$ & $200 \mathrm{~ms}$ \\
\hline Multiroom services $(3 \times$ HD video) & $18 \mathrm{Mb} / \mathrm{s} \mathrm{DL}$ & $50 \mathrm{~ms}$ \\
\hline Real-time network games & $2 \mathrm{Mb} / \mathrm{s} \mathrm{DL}$ and 1 Mb/s UL & $200 \mathrm{~ms}$ \\
\hline Other network games (board games etc.) & $1 \mathrm{Mb} / \mathrm{s} \mathrm{DL} / \mathrm{LL}$ & \\
\hline
\end{tabular}


Table 2

Minimum requirements concerning network access parameters that need to be fulfilled to provide services using a smartphone

\begin{tabular}{|c|c|c|}
\hline Application group & Transmission speed over & Delay of up to \\
\hline \hline $\begin{array}{c}\text { Browsing mobile (or simplified) versions } \\
\text { of web pages or using application }\end{array}$ & $0.2 \mathrm{Mb} / \mathrm{s} \mathrm{DL}$ & $200 \mathrm{~ms}$ \\
\hline Internet TV or video in 480p quality & $0.5 \mathrm{Mb} / \mathrm{s} \mathrm{DL}$ & $200 \mathrm{~ms}$ \\
\hline Internet TV or video in SD quality (720p) & $1.5 \mathrm{Mb} / \mathrm{s} \mathrm{DL}$ & $200 \mathrm{~ms}$ \\
\hline Internet TV or HD video (1080p) & $6 \mathrm{Mb} / \mathrm{s} \mathrm{DL}$ & $200 \mathrm{~ms}$ \\
\hline
\end{tabular}

Table 1 was based on the experience of the largest telcos, collected while working, jointly, on the so-called memorandum on cooperation for improving the quality of services [4]. In addition to the indicators, changes to measurement methods were also suggested, compared to those proposed in [3].

Table 2 lists the minimum parameters for smartphones. Practical use cases show that these values are sufficient for watching IPTV (Internet TV) or movies at lower transmission speeds, thanks to smaller screen sizes and, therefore, lower resolution of videos that need to be downloaded. Examples of transmission speed requirements for high definition (HD), standard definition (SD) and 480p quality thresholds are shown in Table 2.

Based on the research performed, the authors propose that a downstream speed of at least $0.2 \mathrm{Mbit} / \mathrm{s}$ should be considered a minimum QoS requirement. Achieving a downstream speed of at least $1.5 \mathrm{Mbit} / \mathrm{s}$ should be regarded as a service with an average quality level, speeds of at least $6 \mathrm{Mbit} / \mathrm{s}$ should be considered as offering high levels of quality. Due to different packet types used in data transmission, the speed values given above should be considered as averages over $2 \mathrm{~s}$ periods.

The minimum quality speed (i.e. $0.2 \mathrm{Mbit} / \mathrm{s}$ ) does not allow for comfortable use, but one that allows the smartphone user to receive the light-weight e-mails and to view simple, mobile versions of websites with a maximum delay of $200 \mathrm{~ms}$. It is known from practice that such a transmission speed will not be sufficient for watching IPTV (Internet TV) or movies. To ensure the required reliability and quality levels and depending on the resolution of images, video transmission speeds should range from 0.5 to $6 \mathrm{Mbit} / \mathrm{s}$. However, stability of the mobile service parameters is low and depends strongly, inter alia, on the traffic handled, i.e. on the number of active users presented in a given area.

The average throughput of $0.2 \mathrm{Mbit} / \mathrm{s}$, available at a given location may be defined as a threshold value offering reliability of service and the minimum level of quality. On the other hand, reaching the speed of $1.5 \mathrm{Mbit} / \mathrm{s}$ may be defined as a value enabling to achieve reliability of service and the average level of quality. Going further, instead of classic terrain coverage maps, service providers (operators) may publish service availability maps with areas where the service will be available with a $90 \%$ reliability level for transmission speeds of 0.2 and $1.5 \mathrm{Mbit} / \mathrm{s}$.

In practice, such information would be more useful to the user than radio coverage maps, because it would include data on the level of availability and reliability of a given service at a specific location. Doubts concerning the usefulness of coverage maps for telecommunication network users were also expressed in [18].

Evaluation of reliability of services based solely on physical measurements is unrealistic due to the high costs involved. Therefore, the authors propose an evaluation method combining the following:

- measurements relying on testers installed at locations where the minimum level of service is expected,

- based on signal coverage in other areas.

Measurements should be carried out during typical periods of high activity, e.g. between 8 am to $8 \mathrm{pm}$. They should be performed with the test server connected outside the cellular operator's core network, e.g. at the Internet exchange point. The tester should rely on the most popular operating system (Android) and should be operated with typical user settings, i.e. it should be able to work with all available frequencies and access technologies by selecting them freely (free mode), in accordance with the operator's recommendations. Additionally, it is recommended that access to popular applications should be verified as well as social networks, train navigation, local public transport timetables, etc. It has been noticed that applications created for smartphones are better at coping with disruptions to mobile network transmissions than applications viewed with the use of web browser.

\section{Conclusion}

The traditional, indicator-based assessment of QoS allows to perform a basic evaluation of the data plan offered by the service provider (operator) to the user (customer). In such a method, the test equipment measures specific parameters 
determining accessibility of services rendered with the use of the operator's network. Such an assessment offers reliable results for stationary users using dedicated data links (usually the cable). Research performed out in accordance with this method does not take into account, inter alia, limitations caused by the terminal or other user devices, and restrictions imposed by the service provider.

The presented method is not the best solution for evaluating mobile Internet access in a situation in which the operator does not guarantee the advertised access parameters, as these depend on the location, on the user's terminal, on the type of the network made available by the operator and on a range of other conditions. In this case, tests based on assessing the availability and reliability of services are more effective.

Transmission speed threshold values proposed in this paper should be amended in accordance with the needs of users when new transmission technologies are introduced. It is forecast that with the implementation and deployment of 5G networks offering significant transmission capabilities, the level of reliability of IT services will improve considerably.

\section{References}

[1] "TR 101 329. Telecommunications and Internet Protocol Harmonization Over Networks (TIPHON); General aspects of Quality of Service (QoS)" [Online]. Available: https://www.etsi.org/deliver/ etsi_tr/101300_101399/101329/02.01.01_60/

tr_101329v020101p.pdf

[2] "Latin America. Mobile quality of service", GSMA [Online]. Available: https://www.gsma.com/latinamerica/wp-content/uploads/ 2015/12/mobile-quality-of-service-latam-2015.pdf

[3] "ETSI EG 202 057-4. Speech processing, transmission and quality aspects (STQ); User related QoS parameter definitions and measurements" [Online]. Available: https://www.etsi.org/deliver/ etsi_eg/202000_202099/20205704/01.02.01_60/ eg_20205704v010201p.pdf

[4] "Raport z prac realizowanych w ramach memorandum w sprawie współpracy na rzecz podnoszenia jakości usług na rynku telekomunikacyjnym", UKE, 2013, Warszawa [Online]. Available: http://docplayer.pl/1641634-Raport-z-prac-realizowanych-w-ramachmemorandum-w-sprawie-wspolpracy-na-rzecz-podnoszenia-jakosciuslug-na-rynku-telekomunikacyjnym.html (in Polish)

[5] E. Budiman and O. Wicaksono, "Measuring quality of service for mobile internet services", in Proc. 2nd Int. Conf. on Sci. in Informat. Technol. (ICSITech), IEEE, Balikpapan, Indonesia, 2016 (DOI: 10.1109/ICSITech.2016.7852652).

[6] B. Schmidt-Belz, M. Makelainen, A. Nick, and S. Poslad, "Intelligent brokering of tourism services for mobile users", in Informat. and Commun. Technol. in Tourism, K. Wöber, A. Frew, M. Hitz, Eds. pp. 275-284, Springer, 2002 (ISBN: 3211837809).

[7] BEREC, "Guidelines detailing quality of service parameters" [Online]. Available: https://berec.europa.eu/eng/document_register/ subject_matter/berec/regulatory_best_practices/guidelines/9043berec-guidelines-detailing-quality-of-service-parameters

[8] Directive (EU) 2018/1972 of the European Parliament and of the council of 11 December 2018 establishing the European Electronic Communications Code, Official J. of the EU, 2018 [Online]. Available: https://eur-lex.europa.eu/legal-content/ EN/TXT/PDF/?uri=CELEX:32018L1972\&from=EN

[9] Recommendation ITU-T Y.2617, "Quality of service guaranteed mechanisms and performance model for public packet telecommunication data networks" [Online]. Available: https://www.itu.int/rec/ T-REC-Y.2617-201606-I/en
[10] "ETSI TR 103 559. Speech and multimedia Transmission Quality (STQ); Best practices for robust network QoS benchmark testing and scoring" [Online]. Available: https://www.etsi.org/deliver/ etsi_tr/103500_103599/103559/01.01.01_60/ tr_103559v010101p.pdf

[11] M. Kowalewski, Usługi Teleinformatyczne Administracji Publicznej. Warszawa: OWPW, 2019 (ISBN: 9788378149323) (in Polish)

[12] D. M. Curpen, M. Alexandru, and O. Croitoru, "Considerations about the reliability of telecommunications systems", in Proc. 7th Int. Conf. on Electromechanical and Power Systems, no. 33, Iași, Romania, 2009 [Online]. Available: http://elth.ucv.ro/fisiere/anale/ 2009/11.pdf

[13] H. F. H. Omar, K. B. Saadan, and K. B. Seman, "Determining the influence of the reliability of service quality on customer satisfaction: the case of Libyan e-commerce customers", Int. J. of Learning and Development, vol. 5, no. 1, 2015

(DOI: 10.5296/ijld.v5i1.6649).

[14] J. P. Carvallo and X. Franch, "Extending the ISO/IEC 9126-1 quality model with non-technical factors for COTS components selection", 2006 (DOI: 10.1145/1137702.1137706).

[15] "A simple premise for a sophisticated methodology", RootMetrics [Online]. Available: https://www.rootmetrics.com/en-US/ methodology

[16] D. Hoyle, ISO 9000: Quality Systems Handbook, 4th ed. San Diego: Butterworth-Heinemann, 2001 (ISBN: 9780750644518).

[17] R. Kobus, "Jakość usług telekomunikacyjnych czynnikiem kreującym rozwój społeczeństwa informacyjnego”, Ekonomiczne problemy tączności, no. 12, pp. 197-209, Szczecin, Poland, 2011 (in Polish)

[18] TELKO, "Rz: Nowy prezes UKE o rynku telekomunikacyjnym" [Online]. Available: https://www.telko.in/ rz-nowy-prezes-uke-o-rynku-telekomunikacyjnym (in Polish)

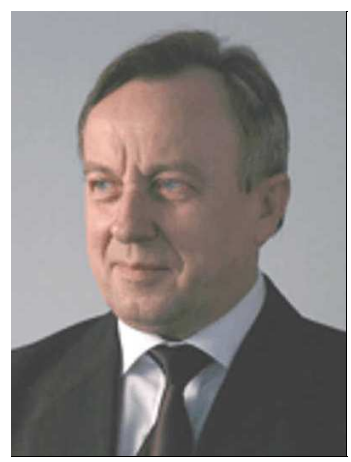

Marian Kowalewski graduated from the Military Academy of Telecommunications in Zegrze (1975). He was an academic teacher, research worker and vice-chancellor for education and research at the same Academy (1975-1997), deputy director for science and general matters in NIT (1997-2004). $\mathrm{He}$ is a Professor at the National Institute of Telecommunications and at Warsaw University of Technology. Head of TETRA project in NIT (since 2002), scientific manager of the IT System of the Country's Protection Against Extreme Hazards project (ISOK) in NIT (2011-2012), Intelligent Transport Systems (ITS) in NIT (2011-2013), cybersecurity (2014-2017). Organizer and co-organizer of many seminars and scientific conferences, author of numerous textbooks, academic course books, articles and R\&D works concerning telecommunications problems. His scientific interests are planning and developing of telecommunications, telematics systems, and their efficiency.

(DD) https://orcid.org/0000-0001-6509-5141

E-mail: m.kowalewski@il-pib.pl

National Institute of Telecommunications

Szachowa 1

04-894 Warsaw, Poland 


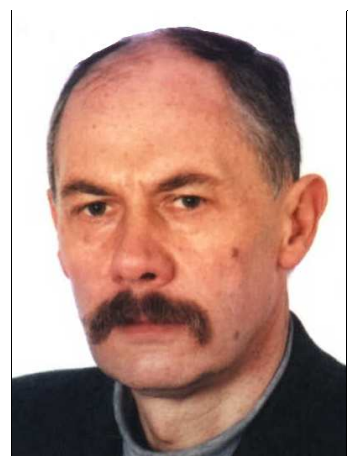

Ryszard Kobus received his B.Sc. and M.Sc. degrees from the Faculty of Electronics of the Warsaw University of Technology in 1975. He worked at the National Institute of Telecommunications since 1975 to 2020. He is a member of the Expert Technical Committee CEN/TC 331 specializing in postal services, and the deputy chairman of the Postal Service Committee PKN/TC 259. $\mathrm{He}$ is a co-author of many patented telecommunications solutions. His research interests include: telecommunications, measurements and evaluation of quality of telecommunications services, quality surveys, evaluation the quality of postal services, standardization.

(i) https://orcid.org/0000-0001-7783-2794

E-mail: rys@r-kobus.eu

National Institute of Telecommunications

Szachowa 1

04-894 Warsaw, Poland

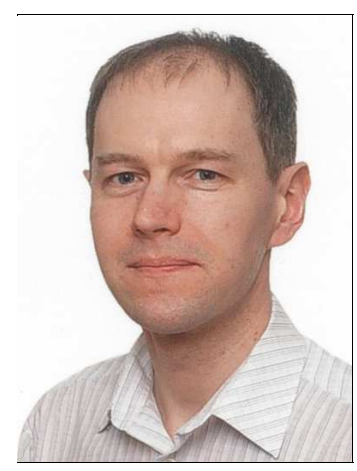

Tomasz Sędek received his B.Sc. and M.Sc. degrees from the Faculty of Electronics and Information Technology of the Warsaw University of Technology in 1997. He has been working at the National Institute of Telecommunications since 1996. His research interests include: telecommunications, measurements and evaluation of quality of telecommunications services, EMF measurements and analysis of results, statistical analysis of big data.

(iD) https://orcid.org/0000-0002-0416-4083

E-mail: t.sedek@il-pib.pl

National Institute of Telecommunications

Szachowa 1

04-894 Warsaw, Poland 